\title{
МОВА ВОРОЖНЕЧІ В РЕГIОНАХ: СУЧАСНІ НАДБАННЯ В ОДЕСЬКИХ МЕДІА
}

\author{
Тетяна Кузнсцова \\ Національний університет «Одеська юридична академія» \\ Фонтанська дорога, 23, 65009, Одеса, Украӥна \\ e-mail: arnautova.tv@gmail.com \\ https://orcid.org/0000-0003-4635-0922
}

Стаття присвячена проблемі вияву мови ворожнечі в сучасних українських 3МІ. Зокрема, в роботі представлено результати проведеного протягом 2016-2018 рр. моніторингу одеських мас-медіа, що демонструє основні тенденції вияву мови ворожнечі. Встановлено, що основними об'єктами ненависті в одеських мас-медіа є українсько-російські відносини, представники етнічних та національних груп, мешканці окремих регіонів та окремі соціальні групи.

«Найпотужнішим» об’єктом за інтенсивністю вияву ворожнечі за аналізований період стали представники етнічних та національних груп. За нашими даними, стосовно цих груп журналісти припускаються використання некоректних характеристик, негативного контексту, необгрунтованої актуалізації приналежності людини до певної етнічної групи. Використані цитовані матеріали (без журналістського коментаря) містять не лише негативно-оцінні слова та вислови, а й відкриті погрози, заклики до знищення, що й призводить до розпалювання міжнаціональної ворожнечі та ненависті. У деяких матеріалах простежується емоційне посилення контексту шляхом використання некоректних найменувань та негативних оцінок.

Ключові слова: мова ворожнечі, мас-медіа, дискурс ненависті, дискримінація.

У нинішній ситуації однією з активно обговорюваних і поряд з цим однозначно не вирішеною є проблема «мови ворожнечі». I справа навіть не в тому, що на сьогодні ще немає однозначно прийнятого визначення цього явища. Сьогодні активно ведуться дискусії стосовно того, чи варто себе поводити етично зі своїм ворогом, тим більше в ситуації реальної війни. Хоча, з іншого боку, виникають питання: а чи завжди ця ворожнеча справді стосується нашого ворога? А чи не породжуємо ми самі собі нових ворогів, необізнано користуючись мовою, порушуючи норми і стандарти журналістики?

Поняття «мова ворожнечі» запозичене лінгвістами із соціології. У 1960-х рр. зарубіжні соціологи дійшли висновку, що для підтримки стабільного балансу в суспільстві потрібен постійний моніторинг мови політики і суспільно відкритих каналів комунікації з метою виявлення агресії. Цей напрямок соціального регулювання

(C) Кузнєцова Т., 2019 
здебільшого залежав від успіхів соціопсихотерапії, яка досліджувала питання зв'язку між рівнем особистої тривоги та соціальною агресивністю, яка стала розглядатися як щось украй небезпечне та небажане. Комунікативні дослідження цього явища активно розпочалися в Свропі та США з кінця 90-х рр. минулого століття, коли предметом уваги багатьох науковців була проблема дискурсу нерівності. У 1997-1998 pp. голландський учений Т. ван Дейк разом з дослідником із Віденського університету Р. Водак, працюючи над проектом «Racism at the top» («Расизм у верхах»), показали, як дискурс відтворює основні соціальні уявлення про «інших», «чужих» у суспільно-політичному контексті. У статті «Мас-медіа сьогодні: дискурси домінування або дискурси різноманітності» Т. ван Дейк акцентує увагу на ідеологічних змінах і ролі ЗМК у цьому процесі, виявляючи основні трансформації в політичних і медійних дискурсах, наголошуючи на породженні настроїв страху, тривоги, скептицизму в суспільстві [2]. У пострадянському просторі науковці зверталися передусім до лінгвістичних досліджень мовленнєвої агресії, у ході яких виявили сутнісні ознаки цього явища, з'ясували причини його появи, визначили основні різновиди (див., наприклад, праці: $[4 ; 7 ; 12])$. Українські дослідники порівняно недавно розпочали дослідження «мови ворожнечі», звертаючи увагу передусім на специфіку її вияву в медіатекстах (див., наприклад: [3; 6; 8; 9; 10; 11]).

Аналізуючи явище мови ворожнечі, науковці та медіа-експерти, як правило, послуговуються визначенням, поданим у Рекомендаціях Комітету міністрів Ради Європи № 97(20)59, де зазначається, що «мова ворожнечі» - це всі види висловлювань котрі поширюють, розпалюють, підтримують або виправдовують расову ненависть, ксенофобію, антисемітизм та інші форми ненависті, викликані нетерпимістю, в тому числі нетерпимістю, що виявляється у формі агресивного націоналізму та етноцентризму, дискримінації меншин і ворожого ставлення до них, а також іммігрантів та осіб, що за своїм походженням належать до іммігрантів. У цьому сенсі поняття «мова ворожнечі» поширюється на всі висловлювання, які спрямовані проти якоїсь однієї особи або якоїсь визначеної групи осіб [1].

Об'єктом для ненависті, агресії та ворожнечі, зазвичай, є соціокультурна група, яка належить до інших - національностей, етнічних груп, релігій, партій, орієнтацій тощо. Зрозуміло, сила та діапазон вияву цих одиниць можуть бути зумовлені багатьма чинниками, серед яких значну роль сьогодні відіграє соціокультурний контекст, соціокультурний простір і навіть час.

Згідно з оцінкою незалежних громадських організацій, які здійснюють моніторинг інформаційного простору, практика використання «мови ворожнечі» суб'єктами української інформаційної сфери залишається порівняно низькою. Зокрема, за підсумками контент-аналізу, здійсненого у серпні 2015 р. експертами українського об'єднання «Центр контент-аналізу», встановлено, що рівень використання «мови ворожнечі» в українських медіа не є високим $(1,7 \%$ від кількості повідомлень на тему Донбасу, Криму та Росії [3]. Проте мова ворожнечі знаходить свій вияв не лише стосовно українсько-російських відносин, а й стосовно багатьох соціокультурних груп, про що свідчить проведений нами моніторинг українських медіа південного регіону.

Зокрема 3 метою визначення специфіки вияву мови ворожнечі у сучасному інформаційному просторі південного регіону України нами було проведено моніторинг матеріалів популярних онлайн-видань міста Одеси («Таймер», «УСИ Одесса», 
«Odessit», «048», «Думская)» за період з 1 червня 2016 року до 1 червня 2018 року. У рамках цього моніторингу у фокусі нашої уваги були такі групи:

- особи за статевою ознакою;

- представники різних релігійних течій;

- мігранти/біженці;

- внутрішньо переміщені особи;

- представники різних етнічних груп;

- представники різних соціальних груп.

У ході аналізу встановлено, що сьогодні основними об'єктами ненависті в одеських мас-медіа $є$ українсько-російські відносини, представники етнічних та національних груп, мешканці окремих регіонів та окремі соціальні групи.

«Найпотужнішим» об'єктом за інтенсивністю вияву ворожнечі за аналізований період стали представники етнічних та національних груп. Одним з найрезонансніших випадків міжетнічної пропаганди стала антиромська інформаційна кампанія у серпні-вересні 2016 р. після трагічного інциденту в селі Лощинівка Ізмаїльського району Одеської області.

До проявів мови ворожнечі в даному випадку можна віднести публічні заяви офіційних посадових осіб, зокрема коментарі чинного на той час голови Одеської обладміністрації М. Саакашвілі; рішення органів місцевої влади, що публічно зайняли позицію захисту тих, хто здійснив самосуд над ромською спільнотою; прямі дії (формування пікетів, протестних груп) членів окремих суспільно-політичні рухів радикального спрямування. Низка загальнонаціональних та регіональних медіа («Українська правда», ICTV, «Бесарабія.inform», «Одеса.depo» та ін.), висвітлюючи цей інцидент, дотримувались позиції прихованого або відкритого співчуття учасникам погрому, поширювали неперевірену інформацію, оперуючи не фактами, а стереотипами щодо однієї сторони протистояння (вказували на приналежність підозрюваного до ромської національності та посилались на неперевірену інформацію щодо наявності в селі наркопритону, організованого місцевою ромською спільнотою) (дет. див.: http://www.niss.gov.ua/content/articles/files/mova-8ele2.pdf).

Журналісти в матеріалах відкрито вказували національність підозрюваного (у багатьох випадках без рішення суду прямо називали його вбивцею та гвалтівником), використовували образливе та стереотипне «циган», протиставляли ромську громаду місцевим жителям чи іншим національностям тощо. Порівняйте: «Цыганские банды терроризируют Николаев, а правоохранители бездействуют. Жители ромской национальности, с тихого согласия правоохранителей, превратили один из микрорайонов намего города в рассадник преступности. Именно в микрорайоне Ялты Заводского района г.Николаева цыганская преступная группировка на протяжении многих лет держит в страхе местное население (...) Цыгане охватили практически все виды преступной деятельности: наркоторговля, воровство, мотенничество, торговля людьми, грабежи и т.д. Криминогенная обстановка в микрорайоне растет, а преступления, совершаемые иьганами, становятся все более дерзкими и жестокими» (http://podrobnosti.mk.ua/2016/03/22/cyganskie-bandyterroriziruyut-nikolaev-a-pravoohraniteli-bezdeystvuyut.html); «Протистояння в селі Лочинівка триває: жителі формують загони самооборони» (http://azov.press/ukr/ protistoyannya-v-seli-loschinivka-triva-zhiteli-formuyuyut-zagonisamooboroni); «B селi на Одещині вбили дитину: громада влаштувала погроми, вимагає виселити ромів» 
(http://www.pravda.com.ua/news/2016/08/28/7118910/15); «Вбивство 9-річної дитини в Лощинівиі: завтра за ииганами приїдуть вантажівки» (http://fakty.ictv.ua/ua/proiss hestvija/20160828-1593013/16); «В Лощчинівиі, де вбили дівчинку, знаходиться наркопритон» (http://odesa.depo.ua/ukr/odesa/v-loshchinivtsi-de-vbili-divchinku-znahoditsyanarkopriton--29082016094300).

Щодо інших випадків використання мови ворожнечі стосовно етнічних груп в одеських медіа, то можемо виділити випадки, як правило, м'якої мови ворожнечі, що виявлялася через негативно-оцінні характеристики, «ворожі» ярлики, недоцільне використання назв національної та етнічної приналежності, що й сприяло створенню стереотипного образу національних меншин як ворога. Ця тенденція найчастіше простежується в матеріалах, в яких висвітлюються проблеми криміналу, ДТП: журналісти часто невмотивовано зазначають національність підозрюваних у здійсненні того чи іншого злочину або учасників надзвичайної події. Крім того мають місце використання в матеріалах найменувань етнічної групи з ярликами «бандити», «вбивці» до прийняття судового рішення. Порівняйте: «Сотрудники полиции задержали членов банды похитителей и вымогателей, состоящей из выходиев из Кавказского региона» (048. - 17.03.2018); «В Одесской области задержсали румына с наркотиками» (Одесса онлайн. - 11.02.2018), «В Одессе патриоты задержали путинских молдован» (048. - 20.05.2017); «В СБУ нашли новых врагов Украины:: одесских болгар, гагузов, русинов и венгров» (Таймер. - 17.03.2017); «Стрельба возле одесского суда: полиция разыскивает банду грузин» (Таймер. - 1.12.2016); «В одесском аэропорту задержали турка, подозреваемого в терроризме» (УСИ. - 5.12.2016).

Як бачимо, у текстовому просторі створені журналістами образи «своїх» та «чужих» національностей і етнічних груп перебувають в опозиції. При цьому спрацьовує стереотип сприйняття «чужого» передусім як загрози для «своїх». Занурюючи назву національності чи етнічної групи в негативний контекст, стверджуючи про іï кримінальність до судового рішення, журналіст тим самим створює їх негативний образ, позиціонує як джерело кримінальної загрози, а це, у свою чергу, призводить до дискредитації групи в цілому.

У ході моніторингу поряд з необгрунтованою актуалізацією приналежності людини до певної етнічної групи, також зафіксовано випадки використання некоректних одиниць й стосовно окремих соціальних груп. Зокрема, в окремих текстах має місце лексема «нелегали» замість більш коректного і рекомендованого міжнародними правозахисними організаціями «мігранти без документів». Порівняйте: «В Одессе обнаружсили тридиать азиатов-нелегалов» (Таймер. - 28.03.2017), «В Коблево задержали 12 нелегалов (Таймер. - 29.06.2017), «Одесская область: на гранище с Молдовой задержали нелегальных мигрантов и их проводника» (Думская. - 1.01.2017).

Стійка тенденція використання некоректних лексичних одиниць простежується й стосовно осіб, які не мають житла: замість нейтральної назви «особи без місця проживання» журналісти використовують некоректне найменування «бомжі». Поряд 3 цим журналісти не лише подають некоректну назву цієї соціальної групи, а й активно занурюють її в негативний контекст, позиціонують групу як джерело загроз, що сприяє стійкості сформованому негативного образу та негативного стереотипу щодо цих людей. Наприклад: «Неизвестные бомжеватого вида оседлали одесский трамвай» (048. - 3.02.2018), «Парк Горького закроют из-за «скопления бомжей, хулиганов, алкоголиков» (УСИ Одесса. - 8.07.2017), «Одесситы бояться хо- 
дить по парку Шевченко из-за бомжей» (Таймер. - 17.06.2017), «В парке Шевченко в 200-х метрах от здания администрации парка живут и гадят бомжи» (Таймер. 17.06.2017).

У ході проведеного моніторингу була виявлена тенденція й щодо порушення стандартів у гендерній тематиці, які можна умовно розділити на дві групи: формування/підтримка гендерних стереотипів та використання некоректної лексики щодо жінок. За нашими даними, у мас-медійних матеріалах, героями/експертами яких $є$ жінки, автори допускають презентацію жінки як сексуального об’єкта, підкреслюють їі більш низький рівень інтелектуальних здібностей, заперечують ділові якості жінки-політика тощо. Наприклад, ось як презентовано в одному журналістському матеріалі депутата Надію Савченко: «Взирая на статную, с хорошо развитьлми формами красавииу, представил себе, как тягостно было современникам настоящей Жанны наблюдать за уходом в небытие такого классного тела»; “Что до арестованной барышни, будем надеяться, у нас с ней ещче всё впереди»»; "Что ж, иногда слова важнее дел, как это случилось с нашими «можновладияами», усльтавшими из уст красавицы всё, что они хотели о себе усльишать, и даже немножечко больше» (Херсонці. - 25.03.2018). В іншому матеріалі журналіст допускає принизливі характеристики жінки-слідчої: «Одесса: пьяная следовательница устроила ДТП, а потом показала «стрептиз» (Таймер. - 1.08.2018).

Найактивніше некоректна та образлива лексика в аналізованих медіа стосувалася представників ЛГБТ. Найпоширенішими порушеннями виявилися трансляція і тиражування негативних стереотипів про ЛГБТ, позиціонування групи як джерела загрози, ствердження про неповноцінність та моральні недоліки, як-от: “Священники окропили иееттр Одессы святой водой после гей-парада» (Таймер. - 18.08.2018), «Одесские «свободовиьы» оещзают сорвать гей-парад без насилия» (Таймер. 12.08.2018).

Некоректне ставлення подекуди траплялося й стосовно людей з обмеженими можливостями, яких у мас-медіа називають інвалідами (замість більш коректного і рекомендованого міжнародними правозахисними організаціями «люди з обмеженими можливостями»), як-от: «Владелец кафе в Лузановке перекрыл инвалидам доступ на пляж» (Таймер. - 12.07.2017), «На 11 станции Фонтана появится современный пляж для людей с инвалидностью» (Таймер. - 15.02.2018).

Щодо українсько-російських відносин як джерела мови ворожнечі, то в одеських ЗМІ найактивніше дискурс ненависті стосовно стосунків України-Росії проявлявся у мас-медійних матеріалах у травні, що зумовлено передусім подіями в Одесі 2 травня 2015 року. Саме в цей час з'являється найбільша кількість матеріалів, в яких висвітлюються проблеми «сепаратизму», які привертають увагу читача досить агресивними заголовковими комплексами, що, у свою чергу, сприяє концентрації негативно-оцінного потенціалу всього мас-медійного матеріалу. Використання «ворожих» мовних одиниць у сильних позиціях тексту не лише свідчить про активізацію маніпулятивних технологій (наприклад, привернення уваги читачів до матеріалу), а й залякування та нагнітання загрози, посилення образу ворога тощо. Порівняйте: «В Одессе на Куликовом поле будут вычислять сепаратистов и «ватников» (048. 1.05.2017), «В Одессе у коллаборачиионистов проводят обыски» (048. - 2.05.2017), «В Одессе на сепаратистском автомобиле задержали избитых «ватников» (048. 9.05.2017), «Одесский «майдановеиџ» перепуган: в городе живут толпь «ватников», 
ждущих своего часа!» (Таймер. - 9.05.2017), «Под Одессой 9 мая обернулось в «ватный» шабаш» (https://www.048.ua/news/1647550).

Найчастіше «мова ворожнечі» стосовно українсько-російських відносин має місце у цитованих журналістами матеріалах, що вирізняються різко вираженим негативно-оцінним потенціалом. Порівняйте: «... проклятый Донбасс, это раковая опухоль Украинь (Таймер. - 31.01.2017), «Майдановка» из Краматорска: если в Николаеве поднимут голову, мочите их лопатой (Таймер. - 7.12.2016), «А что касается предателей: чтоб вы сдохли! Горите вы все в аду! Пусть к каждому из вас придёт злодей, ограбит и убьёт!» (Таймер. - 27.02.2017).

Як бачимо, цитовані матеріали містять не лише негативно-оцінні слова та вислови, а й відкриті погрози, заклики до знищення, що й призводить до розпалювання міжнаціональної ворожнечі та ненависті. У деяких матеріалах простежується емоційне посилення контексту шляхом використання негативних оцінок при характеристиці Донбасу, використання принципу переносу з часткового на загальне, внаслідок чого пересічний споживач інформації може сприйняти: «все, що має відношення до Донбасу, - це зло». Поряд 3 цим журналісти часто не дають жодних коментарів, які б дозволили визначити розмежування між позицією автора та героя матеріалу.

Окрему групу щодо вияву мови ворожнечі становлять українські військослужбовці, які брали участь у військових діях у Донецькому регіоні: деякі журналісти подають негативні матеріали стосовно цих осіб, називаючи їх «атошниками», занурюючи ці номінанти в негативний контекст й тим самим створюючи про цих людей негативні стереотипи. Порівняйте: «В Генштабе заявили, что убитый «атошником» в Киеве повар одесского ресторана сам виноват» (Таймер. - 23.02.2018), «Полиция: «атошники» убили семью кума Януковича» (Таймер. - 15.02.2018); «Пьяный «атошник» из Ровно пугал жену гранатой - пришлось эвакуировать весь дом» (Таймер. 7.05.2018).

Отже, говорячи в цілому про сучасні тенденції вияву «мови ворожнечі» в одеських мас-медіа, можна визнати, з одного боку, порівняно обмежений діапазон вияву риторики ненависті, про що засвідчує незначний перелік її об'єктів (це передусім українсько-російські відносини, національні та етнічні групи, окремі соціальні групи). Поряд 3 цим фіксуємо досить активне вживання окремих негативно-оцінних одиниць, невмотивоване використання некоректних висловів стосовно соціокультурних груп, що й створює сприятливі умови для легітимізації «мови ворожнечі». Активне тиражування таких матеріалів може призводити до формування стійких негативних стереотипів, а також породження нової агресії та ненависті. Адже відомо, мова завжди діє та впливає швидше, аніж ми це помічаємо. Чим більш виразна негативно оцінна характеристика, тим краще вона фіксується у нашій свідомості. Звичка ненавидіти існує довше, аніж толерантність чи вміння розуміти. А «мова ворожнечі» не лише породжує агресію та злість, а й може підштовхувати до відповідних агресивних дій.

I хоча вербальна агресія в сучасному світі оцінюється суспільною свідомістю як менш небезпечна, ніж агресія фізична, однак відомо, що саме вона є першим кроком на шляху агресії фізичної. Тому сьогодні як ніколи дуже актульним для кожного журналіста є відомий вислів: «Преса - це всі новини світу, але не школа злослів’я» $[11,20]$. 


\section{REFERENCES}

1. Recommendation NO. R (97) 20 Of the Committee of Ministers to member states on «hate speech». URL: https://rm.coe.int/CoERMPublicCommonSearchServices/Display DCTMContent?documentId $=0900001680505 \mathrm{~d} 5 \mathrm{~b}$

2. van Dijk T.A. The Mass Media Today: Discourses of Domination or Diversity? // Journal of the European Institute for Communication and Cultural. 1995. Vol. 2. URL: https:// www.tandfonline.com/doi/abs/10.1080/13183222.1995.11008592

3. Дослідження «Практика використання «мови ворожнечі» (hate speech) українськими ЗМІ» [Електронний ресурс] // osvita.mediasapiens. - Режим доступу: http://osvita.mediasapiens.ua/mediaprosvita/research/doslidzhennya_praktika vikoristannya_movi_vorozhnechi_hat e_speech_ukrainskimi_zmi/

4. Какорина Е. В. Стилистический облик оппозиционной прессы / Е. В. Какорина // Русский язык конца ХХ столетия (1985-1995) / В. Л. Воронцова [и др.] ; РАН, Институт русского языка. М. : Языки русской культуры, 1996. С. 409-426.

5. Кронгауз М. Язык мой - враг мой? [Электронный ресурс] / М. Кронгауз // Новый мир. 2002. № 10. Режим доступа : http://www.classes.ru/ru.philology/krongauz-02. htp

6. Кузнєцова Т. В. «Мова ворожнечі» в друкованих ЗМІ (на матеріалі преси Сумщини) / Т. В. Кузнєцова // Вісник Луганського національного університету імені Тараса Шевченка. 2008. № 3 (142). С. 79-85.

7. Купина Н. А. Тоталитарный язык : словарь и речевые реакции / Н. А. Купина. Екатеринбург, Пермь : Изд-во Урал. ун-та, 1995. 448 с.

8. Мова ворожнечі та ЗМІ: міжнародні стандарти та підходи: Проект «Без кордонів» ГО «Центр «Соціальна дія», К., 2015. - Режим доступу: http://noborders.org.ua/wpcontent/uploads/2015/11/guidelines hatespeech media.pdf

9. Мова ворожнечі у 3МІ: якою вона буває та до чого призводить (інфографіка) / Інститут масової інформації, 2014. - Режим доступу: http://imi.org.ua/advices/movavorojnechi-u-zmi-yakoyu-vona-buvae-ta-do-chogo-prizvodit-infografika/

10. Мова ворожнечі: які висловлювання не можна поширювати в 3МI? / Центр демократії та верховенства права, 2017. - Режим доступу: http://cedem.org.ua/ consultations/mova-vorozhnechi-yaki-vyslovlyuvannya-ne-mozhna-poshyryuvaty-vzmi/

11. Прихода Я. Зломова у газетному тексті, або наслідки свободи називання зла / Я. Прихода, Н. Станкевич // Медіа-атака : матеріали Міжнародної конференції «Медіаосвіта як частина громадянської освіти». Львів : Західноукраїнський медіа-центр «Нова журналістика», 2002. С. 28-31.

12. Рускевич К. Риторика ненависті. - Режим доступу: http://liva.com.ua/ritorikanenavisti.html

13. Чічановський А. А. Світ інформації: особистість, суспільство, держава / А. А. Чічановський, В. І. Шкляр. К. ; М. : Вид-во «Слов’янський діалог», 1995. 52 с. 


\title{
THE HATE SPEECH IN THE REGIONS: THE MODERN «ACHIEVEMENTS» IN THE ODESSA MEDIA
}

\author{
Tetiana Kuznietsova \\ National University «Odesa Academy of Law» \\ st. Fontanskaya road 2, 65009, Odesa, Ukraine \\ e-mail: arnautova.tv@gmail.com \\ https://orcid.org/0000-0003-4635-0922
}

The article is devoted to the problem of hate speech spreading by modern mass media. In particular, the work presents the results of the monitoring of Odessa mass media, which will demonstrate the main trends in the revealing of hate speech. It has established that the main objects of the hatred in the Odessa mass media are Ukrainian-Russian relations, representatives of ethnic and national groups, residents of separate regions and separate social groups. Representatives of ethnic and national groups became «the stronges» object in terms of intensifying hate during the analyzed period. According to our data, regarding these groups, journalists are expected to use incorrect characteristics, negative context, unreasonable reference of belonging to a certain ethnic group. The used cited materials (without a journalistic commentary) contain not only negative-evaluative words and expressions, but also open threats, which can appeal for destruction, which leads to incitement in international hostility and hatred.

In the text space journalists created images of «their» and «unfamiliar» nationalities and ethnic groups, which are turned to be in opposition. At the same time, the stereotype of the perception of « unfamiliar « works first of all as a threat to «their». Imposing the name of a nationality or an ethnic group in a negative context, claiming, for example, its criminal prosecution, the journalist thus creates a negative image, posing as a source of a criminal threat, which in turn leads to discrediting the group as a whole. Some materials trace the emotional enhancement of the context by using incorrect names and negative evaluations concerning separate socio-cultural groups. The revealed quoted materials contain not only negativeevaluative characteristics, but also open threats, calls for destruction, which leads to incitement of ethnic hatred. Active replication of these materials may contribute to the formation of stable negative stereotypes, which may generate new aggression and hatred.

Key words: hate speech, mass media, discourse of hatred, discrimination. 